of papers most of which deal with palæobotanical problems, often of very wide general interest. Several papers deal with petioles and rhizomes of zygopterid affinity which tend to the conclusion that the "old and once extensive genus Zygopteris, after many vicissitudes, will probably emerge once more as the largest and most important of the Zygopterideæ". A solitary block of secondary wood found long ago at an unknown locality in the Rajmahal Hills, Bihar, has aroused Prof. Sahni's interest in the vessel-less Dicotyledons, as this wood, undoubtedly of Jurassic age, shows definite affinities with these plants. The block is put in a new genus Homoxylon and the wood of the living genus Tetracentron has been re-examined.

Dr. S. K. Mukerji has interesting papers upon salt distribution in soil (which leads to a re-examination of Liesegang rings) and upon ecological questions, together with a very forceful statement of the need for the compilation of an Indian pharmacopoeia and of increased interest in the commercial plantation and exploitation of Indian medicinal plants. He has also several interesting papers upon the conditions governing the distribution of water plants in Indian freshwater areas.

Dr. H. P. Chowdhury has several papers upon the factors affecting respiration and transpiration in apple fruits, which record several attempts to determine cell size and the comparative extent of inter. cellular space systems, very difficult variables to measure in such fleshy tissues. He has also papers on the algal and fungal vegetation, whilst Dr. S. $K$. Pande has several papers upon Indian liverworts. There are other contributions and other fields of work but this brief review of the contents of this pamphlet, published by the University of Lucknow (1933), shows what signal progress the Indian universities, guided by Indian investigators, are making in biologieal fields of work.

\title{
Photoelectric Theory and Applications
}

$\mathrm{L}^{\mathrm{I}}$ $\mathrm{KE}$ the thermionic valve, the photoelectric cell has evolved during recent years from an interesting scientific novelty into an instrument of everyday commercial application. In such circumstances a large amount of scientific and technical information is published, and the assimilation of this information presents some difficulty to those not actively engaged in the particular field concermed. A useful paper in this connexion was presented to the Television Society on February 14, entitled "Review of the Theory and Applications of Photoelectric Effects" by G. Windred. This paper constitutes a summary of our present knowledge of photoelectric phenomena, with a brief outline of the relevant theory and an indication of some of the applications of modern photoelectric cells.

Treating the subject in historical order, reference is made to the photo-conductivity effect exhibited particularly by selenium. It is shown that the change in conductivity of this substance is proportional to the square root of the energy in the incident light. By suitable construction, a selenium cell may be made to give a current change of 100 milliamperes between dark and light conditions, and in this form it is used to operate relays for a variety of purposes. The selenium bridge has also played an important part in the transmission of sound by light as in the photophone. For many purposes, however, the selenium cell has been eclipsed by the photoelectric cell, which incorporates a substance which liberates electrons under the influence of incident light. The energy of the emitted electrons is proportional to that of the incident light, and the phenomenon is thus exhibited particularly at short wave-lengths.

One form of the modern photoelectric cell employs a cathode with a monomolecular film of potassium or cæsium on oxidised silver in an atmosphere of argon. An altemative form of photoelectric cell has been developed from the copper oxide rectifier; this cell consists of a layer of cuprous oxide on a copper plate forming one electrode, while a conducting gauze is placed in contact with the oxide to form the second electrode. In the latter case, illumination of the oxide surface through the gauze results in the production of electrons which flow from the oxide to copper and produce a current in the external circuit without the aid of a battery or other source of electromotive force. Both these types of photo. electric cell are in widespread use for many scientific and technical purposes, such as photometry, sound films and television.

\section{Radio Research in Great Britain}

CINCE its establishment in 1920 under the $D$ Department of Scientific and Industrial Research, the Radio Research Board has contributed notably to the study of many problems which have arisen in connexion with the science and practice of radio communication. At suitable stages in the course of each investigation, the results are made available either by the issue of special reports through H.M. Stationery Office or by the publication of papers in the proceedings of scientific and technical societies. In addition, summaries of the work are published periodically in the form of Reports of the Radio Research Board, the latest of which covers the period January 1, 1932, to September 30, 1933.*

The date at which an account of the work for the year 1932 would normally have been submitted

* Department of Scientiflc and Industrial Research. Report of the Radio Research Board for the period 1st January 1932 to 30th September 1933. Pp. iv + 137. (London: H.M. Stationery Office, 1934.) $2 s$. $6 d$. net. found the organisation of the Radio Research Board in a state of transition, and the publication of the report under review was therefore intentionally delayed in order that the introduction and first results of two notable improvements in organisation might be dealt with in some detail. These relate to the complete re-organisation of the Committees generally supervising the work of the Board, and the amalgamation of the Wireless Division of the National Physical Laboratory and the Radio Research Station, Slough, into a new Radio Department of the Laboratory. An additional advantage of the delay is that substantial progress is reported in several investigations which had reached only a very preliminary stage at the end of 1932 .

A considerable portion of the report is devoted to investigations on the propagation of electric waves, and particular attention is given to the development and utilisation of new methods of 'echo-sounding' 
of the ionosphere, by which observers on the ground can explore the electrical condition of the atmosphere at heights of 60-150 miles. A preliminary account is given also of the results obtained from the special work carried out during the Second International Polar Year, which covered the thirteen months ended in August 1932. Closely associated with the research on wave propagation has been the study of the angle of incidence and of the varying intensity and polarisation of waves received from distant transmitting stations; while, in another sphere of activity, the development of a practical radio direction-finder which shall be immune from the effects of these varying electric waves, has been continued with considerable success. Attention has also been devoted to the production and study of short electric waves down to wave-lengths of about $15 \mathrm{~cm}$., and to their mode of propagation over the earth's surface. Work which is more of a laboratory rather than field nature has included the maintenance and development of the radio frequency standards at the National Physical Laboratory, and of the methods of measuring various electrical quantities used in radio technique. A now wireless transmitter of somewhat unique design has been installed at the Laboratory during the period under review; while a special investigation was conducted into the problem of interference and receiver selectivity. Finally, the report describes the latest developments made at the Radio Research Station in connexion with the cathode ray oscillograph.

The serious student and expert worker in radio research problems will find much to interest him in the report, while access to more detailed information on the subject is facilitated by the list given in an appendix of publications describing the work of the Radio Research Board during the period under review.

\section{Science News a Century Ago \\ Death of Telford}

Thomas Telford, the first president of the Institution of Civil Engineers, died at his house, 24 Abingdon Street, Westminster, on September 2, 1834, at the age of seventy-seven years. In an obituary of him published in the Annual Register for 1834, it is said that "he was inclined to set a higher value on the success which attended his exertions for improving the great communication from London to Holyhead, the alterations of the line of the road, its smoothness, and the excellence of its bridges, than on the success of any other work he executed. . . . $\mathrm{H}_{\Theta}$ understood algebra well, but held mathematical investigation rather cheap, and always resorted to experiment when practicable, to determine the relative value of any plans on which it was his business to decide. . . Mr. Telford's will was sworn under $£ 35,000$. The testator bequeaths about $£ 3,000$ to divers charitable institutions, and legacies to several persons of mechanical and literary genius, amounting altogether to $£ 16,000$. Among these is a bequest of 500 guineas to Robert Southey, esq., the poet laureate."

\section{Botanical and Horticultural Shows}

It was the custom of J. C. Loudon, the editor of the Gardener's Magazine, to collect and print in his journal, after midsummer, a comprehensive series of reports and notices of the provincial flower shows and kindred exhibitions held in England and in Scottish centres. These were of special importance at the period to cultivators of now plants and shrubs, as well as of great benefit to gardeners and the community in regard to displays of fruit and vegetables. The Beverley Floral and Horticultural Society promoted a gathering of this kind on September 3, 1834, the details of which appeared in the Hull Advertiser. Reference was made to a "brilliant assortment of georginas", the latter term being then in common use. It seems that the president of the Beverley Exhibition took occasion to protest against the adoption of the name Georgina in place of Dahlia. This led Loudon to write as follows: "The genus was named Dahlia in honour of Prof. Dahl a Swedish botanist. Objections were at first made to this name under the erroneous impression that it had already been appropriated to another genus, and this induced Prof. Willdenow in his 'Species Plantarum' to apply a new name, that of Georgina, after Georgi, an eminent Russian traveller and botanist. Mr. David Don has proved to us that the name Dahlia was applied one year before that of Georgina, and that therefore, although the latter name has been adopted in the 'Dictionnaire d'Histoire Naturelle', the former ought to be retained." Loudon then states that it is his intention to use the name Dahlia in all future issues of his publication. (Gardener's Magazine, 1834.)

\section{The Post Office Steam Packet Service}

In the 'twenties of last century, the old sailing packets between England and Ireland and the Continent were superseded by steam vessels, but the mail steamers still continued to be run directly by the Post Office. In a note in the Mechanic's Magazine of September 6, 1834, it is stated that "The Post Office has now twenty-four steam vessels regularly employed in its service; four between Liverpool and Dublin, of about 300 tons each, and 140 horses' power; six between Holyhead and Dublin, of 235 tons and 100 horses' power ; four between Milford and Waterford of from 189 to 237 tons, and 80 horses' power ; two between Port Patrick and Donaghadee of 110 and 130 tons, and 40 horses' power ; three between Weymouth and Guernsey and Jersey of from 154 to 165 tons and 60 horses' power; and five from Dover to Calais and Ostend, of 110 tons each and 40 and 50 horses' power. They perform 2,293 voyages annually."

\section{The Pulkova Observatory}

The suggestion for the construction of an observatory near St. Petersburg was made by the Emperor Nicholas I (1796-1855) in 1830. In the Athenceum of September 6, 1834, it was said: "A new observatory, far surpassing in magnitude every similar establishment is about to be built at St. Petersburg by command of the Emperor. The observatory itself will consist of three towers with moveable cupolas. Two of these towers are to be appropriated to the Konigsberg heliometer and the Dorpat refractor, but the centre tower is destined for the reception of an instrument exceeding in size all others of its kind. In the lower part of the towers the meridian and transportable instruments will be placed. Spacious habitations for five astronomers will be connected by corridors with these towers so that the whole will form a continuous building $510 \mathrm{ft}$. in length. Smaller subordinate buildings, for various purposes, will increase the establishment, for the site of which an eminence between six and seven miles from St. Petersburg has been selected." The foundation stone of the famous observatory was laid on June 21, 1835, and the building was completed on August 19, 1839. 